\title{
Phytosanitary Situation of Maize streak virus in the Main Maize Production Zones of Cameroon
}

\author{
Grace Annih Mbong1,2, Christopher Suh ${ }^{3}{ }^{*}$, Hervé Djomo Sime', Mariette Anoumaa1, \\ Theophile Fonkou', Lysette Laure Chimi Nkombo3 ${ }^{3}$, Silvestro Meseka4, P. Lava Kumar ${ }^{4}$, \\ Menkir Abebe ${ }^{4}$
}

${ }^{1}$ Faculty of Sciences, University of Dschang, Dschang, Cameroon

${ }^{2}$ Ministry of Agriculture and Rural Development, Yaounde, Cameroon

${ }^{3}$ Institute of Agricultural Research for Development, Yaoundé, Cameroon

${ }^{4}$ International Institute of Tropical Agriculture, Ibadan, Nigeria

Email: *suhchristopher@yahoo.com

How to cite this paper: Mbong, G.A., Suh, C., Djomo Sime, H., Anoumaa, M., Fonkou, T., Chimi Nkombo, L.L., Meseka, S., Kumar, P.L. and Abebe, M. (2021) Phytosanitary Situation of Maize streak virus in the Main Maize Production Zones of Cameroon. Agricultural Sciences, 12, 339-353. https://doi.org/10.4236/as.2021.124022

Received: February 18, 2021

Accepted: April 6, 2021

Published: April 9, 2021

Copyright $\odot 2021$ by author(s) and Scientific Research Publishing Inc. This work is licensed under the Creative Commons Attribution International License (CC BY 4.0).

http://creativecommons.org/licenses/by/4.0/

(c) (i) Open Access

\begin{abstract}
Maize streak caused by the Maize streak virus (MSV, genus Mastrevirus) is transmitted by Cicadulina spp., and is responsible for considerable maize yield losses in all maize production zones in Africa, including Cameroon. A survey was conducted in 3 agro-ecological zones (AEZ) of Cameroon (Sudano-Sahelian: zone I, Western Highlands: zone III and Bimodal Rainforest: zone V) between November 2017 and November 2019 to determine the status of streak disease in maize farms. The incidence and severity were determined in 90 maize fields, 30 fields per AEZ; the effect of lightning on the disease was also assessed using 15 fields under shade and 15 opened fields per AEZ. The highest streak disease incidence (60\%) was found in AEZ I, whereas the lowest incidence was $10 \%$ in AEZV. The highest disease incidence and severity ( $80 \%$ and 4.5 respectively) were observed in maize fields under shade as compared to open fields ( $70 \%$ and 4.5 respectively). The phylogenetic analysis of MSV sequences from symptomatic plants indicated it as MSV-A strain identical to be previously reported to determine the virus diversity in relation to the other characterization isolates. This information is important for the development of control strategies to limit yield losses due to MSV.
\end{abstract}

\section{Keywords}

Maize streak virus, Incidence, Severity, Agro-Ecological Zone, Cameroon

\section{Introduction}

Maize (Zea mays L.) is an important staple food for millions of people and is an 
important source of carbohydrates in sub-Saharan Africa [1]. It is also recognized as a staple food ingredient that can provide up to $30 \%$ protein, $60 \%$ energy and $90 \%$ starch in the diet of animals [2]. It is cultivated in all 5 agro-ecological zones of Cameroon. It is the most consumed cereal in Cameroon ahead of rice and sorghum [3]. Among the growing crops in Cameroon, maize occupies the first place. Its increasing demand for animal nutrition and agro-industries has led farmers to take a greater interest in it. Although the number of producers over the years has been increasing and more than one million farmers grow maize as their main crop, its production remains insufficient to satisfy the demand. Maize demand in Cameroon for animal feed and human consumption is estimated at 1,350,000 tons [4]. The annual national demand is estimated at 2.8 million tons for a production of 2.2 million tons in 2019 , i.e. a deficit of 600,000 tons covered by imports [5] [6]. Although maize is the most important cereal in Cameroon, its production faces abiotic and biotic constraints such as viral diseases. Three main viruses are reported on maize crops in tropical regions: Maize Stripe Virus (MStpV); Maize Mosaic Virus (MMV) [7] and Maize streak virus (MSV) [8] [9]. MSV is the most widespread, and is transmitted by several species of the Cicadulina insects, the most widespread being Cicadulina mbila. The advanced symptoms are yellow and elongated chlorotic streaks. These viruses contribute to considerable yield losses in tropical Africa [10]. An epidemic of maize streak disease (MSD) has been reported in many countries in tropical Africa and causes yield losses ranging from $30 \%$ to $100 \%$ [11]. The increase in production in Cameroon is due to the increase in cultivated areas and not to the increase of productivity. However, the control of disease parameters such as Maize streak virus in the different agro-ecological zones of Cameroon could allow the development of control strategies to improve productivity.

Molecular identification of Maize streak virus in Cameroon revealed the first evidence for a subtype A1 isolate; however, this work was performed only in a part of AZE I [12]. Knowledge about MSV disease parameters in different agro-ecological zones of the country is required for the development of control strategies.

The objective of this study was to determine the status of Maize streak virus in different agro-ecological zones of Cameroon in order to develop control strategies.

\section{Materials and Methods}

\subsection{Description of Study Areas}

A survey was carried out between November 2017 and November 2019 in three localities of each of three agro-ecological zone (AEZ) of Cameroon which are the main maize production zones of Cameroun: AEZ I (Mogodé, Figuil, Garoua), AEZ III (Foumbot, Dschang, Ndop) and AEZ V (Ntui, Mbalmayo, Obala) (Figure 1). The characteristics of each AEZ are presented in Table 1. 


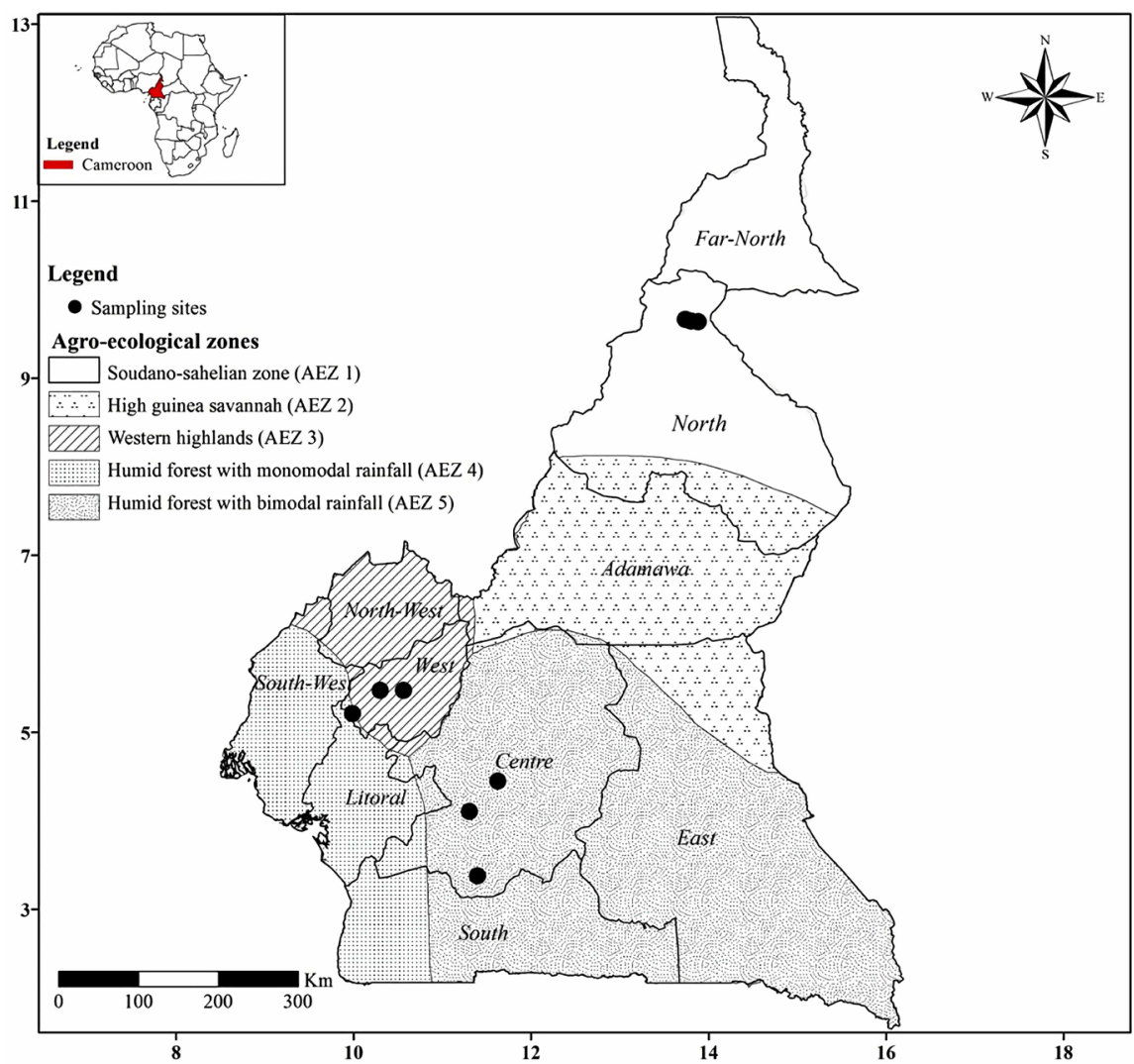

Figure 1. Presentation of agro-ecological zones of Cameroon [13].

Table 1. Characteristics of agro-ecological areas.

\begin{tabular}{|c|c|c|c|c|c|}
\hline Features & Geographic Situation & Altitudes (m) & Precipitation (mm) & Temperature ${ }^{\circ} \mathrm{C}$ & Maize status \\
\hline AEZ I & $\begin{array}{l}8^{\circ} 36^{\prime \prime} \text { to } 12^{\circ} 54^{\prime \prime} \mathrm{N} \\
12^{\circ} 30^{\prime \prime} \text { to } 15^{\circ} 42^{\prime \prime} \mathrm{E}\end{array}$ & $200-600$ & 500 & $28-45$ & Main crop \\
\hline AEZ III & $\begin{array}{l}4^{\circ} 54^{\prime \prime} \text { to } 6^{\circ} 36^{\prime \prime} \mathrm{N} \\
9^{\circ} 18^{\prime \prime} \text { to } 11^{\circ} 24^{\prime \prime} \mathrm{E}\end{array}$ & $1000-2800$ & 2000 & $12-26$ & Main crop \\
\hline AEZ V & $\begin{array}{c}2^{\circ} 6^{\prime \prime} \text { to } 5^{\circ} 48^{\prime \prime} \mathrm{N} \\
10^{\circ} 30^{\prime \prime} \text { to } 16^{\circ} 12^{\prime \prime} \mathrm{E}\end{array}$ & $500-1000$ & 1600 & $20-35$ & Main crop \\
\hline
\end{tabular}

\subsection{Evaluation of the Incidence and Severity of Maize Streak Disease in the Three Agro-Ecological Zones of Cameroon}

The incidence and severity of maize streak disease (MSD) were assessed at the flowering time in 90 fields of at least 0.5 ha. The work was performed in 10 fields randomly selected in each locality during dry and rainy seasons in 2018 and 2019. The fields were separated from each other by a distance of $2 \mathrm{~km}$.

\section{1) Evaluation of MSD incidence}

Within each field, strings were used to draw $100 \mathrm{~m}^{2}(10 \mathrm{~m} \times 10 \mathrm{~m})$ quadrats so that the "W" pattern was used for the impact assessment. The number of plants attacked in each quadrat were recorded and the disease incidence was calculated using the following formula: 


\section{2) Evaluation of MSD severity}

The disease severity was assessed visually using the semi-quantitative scale of Bello et al. [14] Donson et al. [15] which ranges from 1 to 5 depending on the severity of symptoms:

1: the plant presents a few chlorotic spots visible during a very detailed inspection;

2: the plant shows an easily visible but slight streak;

3: $60 \%$ of the plant shows a striation;

4: $75 \%$ of the plant shows a significant streak with dwarfism;

5: more than $75 \%$ of the plant is fully attacked in a very severe manner with very important dwarfism.

\subsection{Sample Collection and Molecular Analyses}

Symptomatic young leaves without fungal lesions of approximately 2 inches were collected, wrapped in hydrophilic paper, inserted in labelled envelopes and kept for molecular analysis.

\subsection{Serological Analysis of Leaves Sample for Maize Streak Virus Detection}

ELISA test was performed on maize leaf samples to confirm the presence of MSD before proceeding with molecular analysis using the protocol described by Clark, and Adams [16] and Thottappilly et al. [17].

\subsection{DNA Extraction}

DNA extraction was carried out at the IITA in Ibadan from fresh MSV infected leaf samples using a modified CTAB method [18].

30 to $50 \mathrm{mg}$ dry corn leaves were crushed using a Vortex. To do so, the dry leaves were put in a $2 \mathrm{ml}$ tube then 2 to 3 beads were added and placed on the vortex rack for grinding until a very fine powder was obtained. Then, after removing the beads, lysis buffer preheated to $60^{\circ} \mathrm{C}$ in a water bath was added. The cell lysis buffer consists of the following components: Cetyl Trimetyl Ammonium Bromide (CTAB) 2\%, NaC $11.4 \mathrm{M}$, Glucose $0.5 \mathrm{M}$, Etylene Diamine Tetra acetic Acid (EDTA) $20 \mathrm{mM}$ and Tris- $\mathrm{HCl}$ or Trizma base pH8 $100 \mathrm{mM}$. We used chloroform-isoamyl alcohol in the ratio 24:1 for the precipitation of cellular proteins, then isopropanol for the precipitation of nucleic acids and finally $70 \%$ ethanol for their washing. The extracted DNA was suspended in $100 \mu \mathrm{l}$ sterile distilled water and stored at $-20^{\circ} \mathrm{C}$ for analysis.

\subsection{Amplification}

The extracted genomic DNA was amplified by PCR using the following primers: MSV 1770-1792 (C1): MSV 215-234 (C2): 5'-TTGGVCCGMVGATGTASAG-3'; 
and 5'CCAAKDTCAGCTCCTCCG-3' where the ambiguity codes are $\mathrm{M}=\mathrm{A}$ or $\mathrm{C} ; \mathrm{K}=\mathrm{G}$ or $\mathrm{T} ; \mathrm{S}=\mathrm{C}$ or $\mathrm{G} ; \mathrm{V}=\mathrm{A}$ or $\mathrm{C}$ or $\mathrm{G}$; and $\mathrm{D}=\mathrm{A}$ or $\mathrm{G}$ or $\mathrm{T}$. These primers for $\mathrm{C} 2 / \mathrm{C} 1 \mathrm{ORF}$ regions are described by Van Antwerpen and Rutheford [19]. The primers amplified the fragments to $900 \mathrm{bp}$. PCR was performed using an AMP PCR System 9700. Amplification was performed in a reaction of $25 \mu \mathrm{l}$ containing $2 \mu \mathrm{l}$ of DNA; $3.5 \mu \mathrm{l}$ of primer; $0.625 \mu \mathrm{l}$ of $10 \mathrm{mM}$ dNTP mix; $0.16 \mu \mathrm{l}$ of taq DNA polymerase; $2.5 \mu \mathrm{l}$ of buffer $3.5 \mu \mathrm{l}$ of $25 \mathrm{mM} \mathrm{Mg} \mathrm{Cl}$. The PCR was performed with 35 cycles of $94^{\circ} \mathrm{C}$ for 5 minutes, $60^{\circ} \mathrm{C}$ for 1 minute, $72^{\circ} \mathrm{C}$ for 2 minutes, $72^{\circ} \mathrm{C}$ for 10 minutes. The PCR products were evaluated by electrophoresis in $1.2 \%$ agarose gel in TEB buffer soaked with ethyl bromide and visualized under ultraviolet light.

\subsection{Purification and Sequencing}

The reaction medium to be purified was subjected to an extraction with phenolTris/chloroform/isoamyl alcohol (respective proportions: 25/24/1) then the DNA was precipitated by addition of 2 volumes of absolute ethanol in the presence of $200 \mathrm{mM} \mathrm{NaCl}$ and $5 \mu \mathrm{g}$ glycogen. After centrifugation at $4^{\circ} \mathrm{C}$ for $15 \mathrm{~min}$ at $15,000 \mathrm{rpm}$, the DNA pellet was washed with $70 \%$ ethanol, dried and resuspended in water.

Sequences were assembled and edited using MEGA 6, MSV genome sequences were obtained from GenBank. Sequence sub-sequence realignment tool implemented in MEGA. Phylogenetic trees were constructed by the neighbor-joining (Jules-Cantor distances, 1000 bootstrap replicates) and maximum-likelihood (Hasegawa-Kishino-Yano model, transition/trans version ratio inferred from the data and 100 bootstrap replicates) methods implemented in MEGA respectively. Recombination was analyzed using the RDP, Default settings were used throughout and only potential recombination events detected by the above method coupled with phylogenetic evidence of recombination were considered significant. Also, the severity of Bonferroni correction during detection was minimized by only searching for recombination signals in a single sequence within groups of sequences sharing $99.7 \%$ sequence identity. Composite likelihood estimates (CLEs) of population-scaled recombination rates and estimates of population-scaled mutation rates were inferred using the PAIRWISE component of LDHAT. Site-to-site variation in the CLE of the population-scaled recombination rates was assessed using the INTERVAL component of LDHAT.

\subsection{Data Analysis}

Generalized linear models (GLMs) were used to analyze data on the incidence and severity of MSV collected in agro-ecological zones as described by Wichura [20] using JMP version 8 software. Mean values among different agro-ecological zones, and localities were separated by the Tukey-Kramer test at $5 \%$ probability threshold $(\mathrm{P} \leq 0.05)$.

To understand the implication of any new virus strain, the complete genomes 
of isolates from 6 Cameroonian MSV (MSV-CAM) were compared to the reference MSV isolates available at IITA, Ibadan and those available in the gene bank of the National Center for Biotechnology Information (NCBI).

The phylogenetic tree of $6 \mathrm{MSV}$ isolates compared to the IITA reference isolate MSV was constructed using the maximum likelihood method based on the model of Kumar \& Nei [21]. The branches corresponding to partitions reproduced in less than $50 \%$ of the bootstrap replicates $(\mathrm{N}=1000)$ are reduced. All positions containing gaps and missing data were removed.

\section{Results}

\subsection{Incidence of MSD}

The incidence of MSV in the different agro-ecological zones during the years 2018 and 2019 is presented in Figure 2(a). Agro-ecological Zone V had the lowest incidence in both seasons, while AEZ I had the highest incidence, although there were seasonal differences. In 2018, the highest incidence was observed in the dry season in all AEZ zones (29\%, 44\% and 58\% in AEZ V, AEZ III and AEZ I respectively) compared to the wet season (7\%, 26\% and $46 \%$ in AEZ V), In 2019, the dry season had the highest incidence in all AEZs (17\%, $42 \%$ and 50\% in AEZ V, AEZ III and AEZ I respectively) compared to the rainy season (7\%, $31 \%$ and $42 \%$ in AEZ V, AEZ III and AEZ I respectively) (Figure 2(b)).

Plot lightning had a significant effect on the MSD incidence in all agro-ecological zones. Shaded plots had significantly higher incidences than opened plots (Figure 3).

\subsection{MSD Severity}

The severity of MSD in the different agro-ecological zones is shown in Figure 5. For both years the severity did not vary at all. The highest severity on the rating scale used was noted in Western highland in the dry season (4), which is the Sudano-Sahelian zone. The lowest severity was recorded in the rainy season in agro-ecological zone V (Figure 4).



(a)

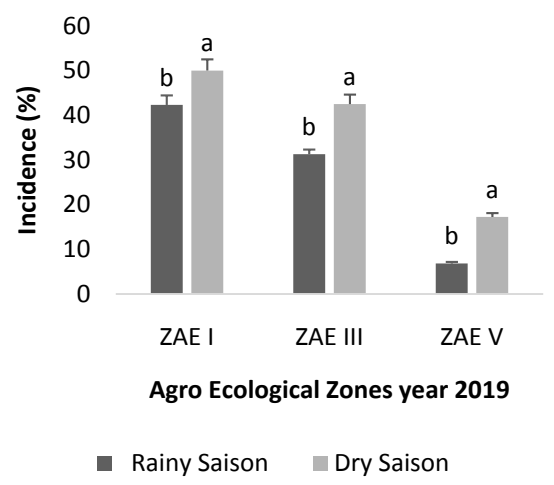

(b)

Figure 2. Incidence of maize streak disease in different agro-ecological zones during dry (a) and rainy seasons (b). 


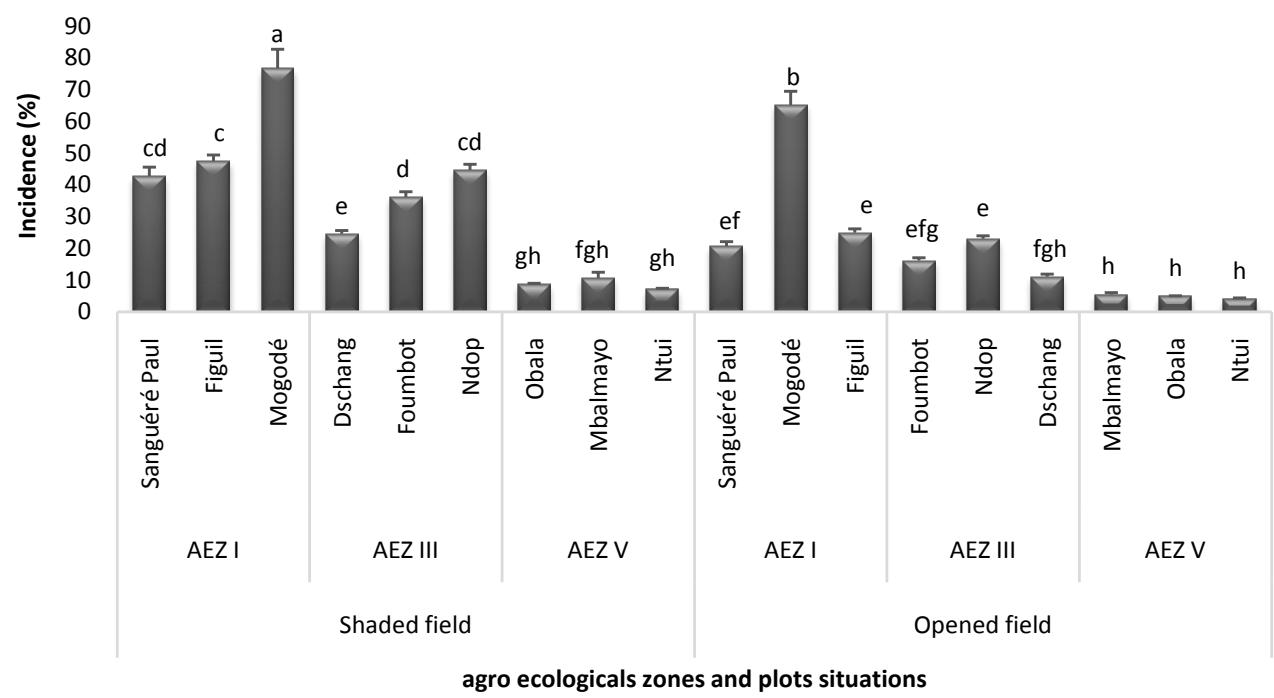

Figure 3. Incidence of maize streak disease in different localities of each agro-ecological zones according to plot lightning. Sample means, and error bars are standard errors of the mean. Mean followed by the same letter are not significantly different (Tukey's HSD test, $\mathrm{P}=0.05$ ). AEZ: Agro Ecological Zone.

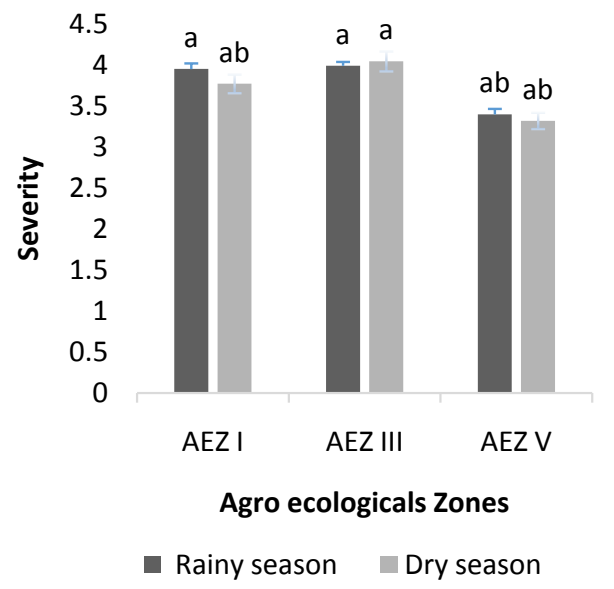

(a)

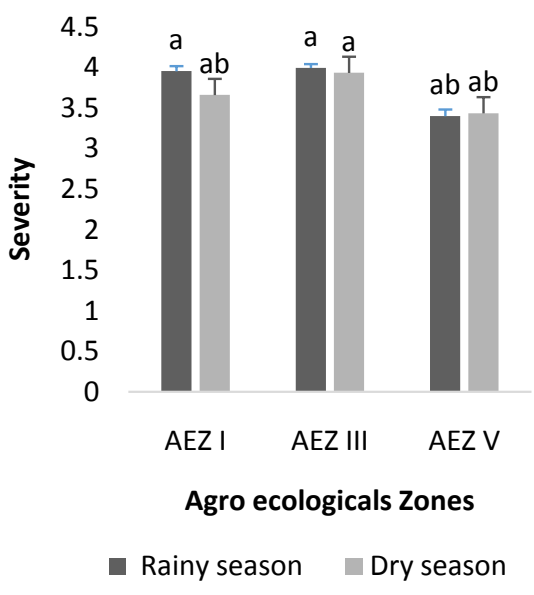

(b)

Figure 4. Severity of maize streak disease in less different agro-ecological zones in 2018 (a) and 2019 (b). Sample means, and error bars are standard errors of the mean. Mean followed by the same letter are not significantly different (Tukey's HSD test, $\mathrm{P}=0.05$ ). AEZ: Agro-Ecological Zone.

Figure 5 shows that the location of the plots has a significant effect on the severity of MSD in all agro-ecological zones. The plots that were in the shade had high severity compared to the plots that were in the open (Figure 5).

\subsection{Epidemiological Status of Maize streak virus in Cameroon}

The investigation realized during the two last year allowed to list 12 varieties in 2018 and 17 varieties in 2019 all coming from IRAD.

Figure 6 shows the effect of maize varieties on MSD incidence and severity of 


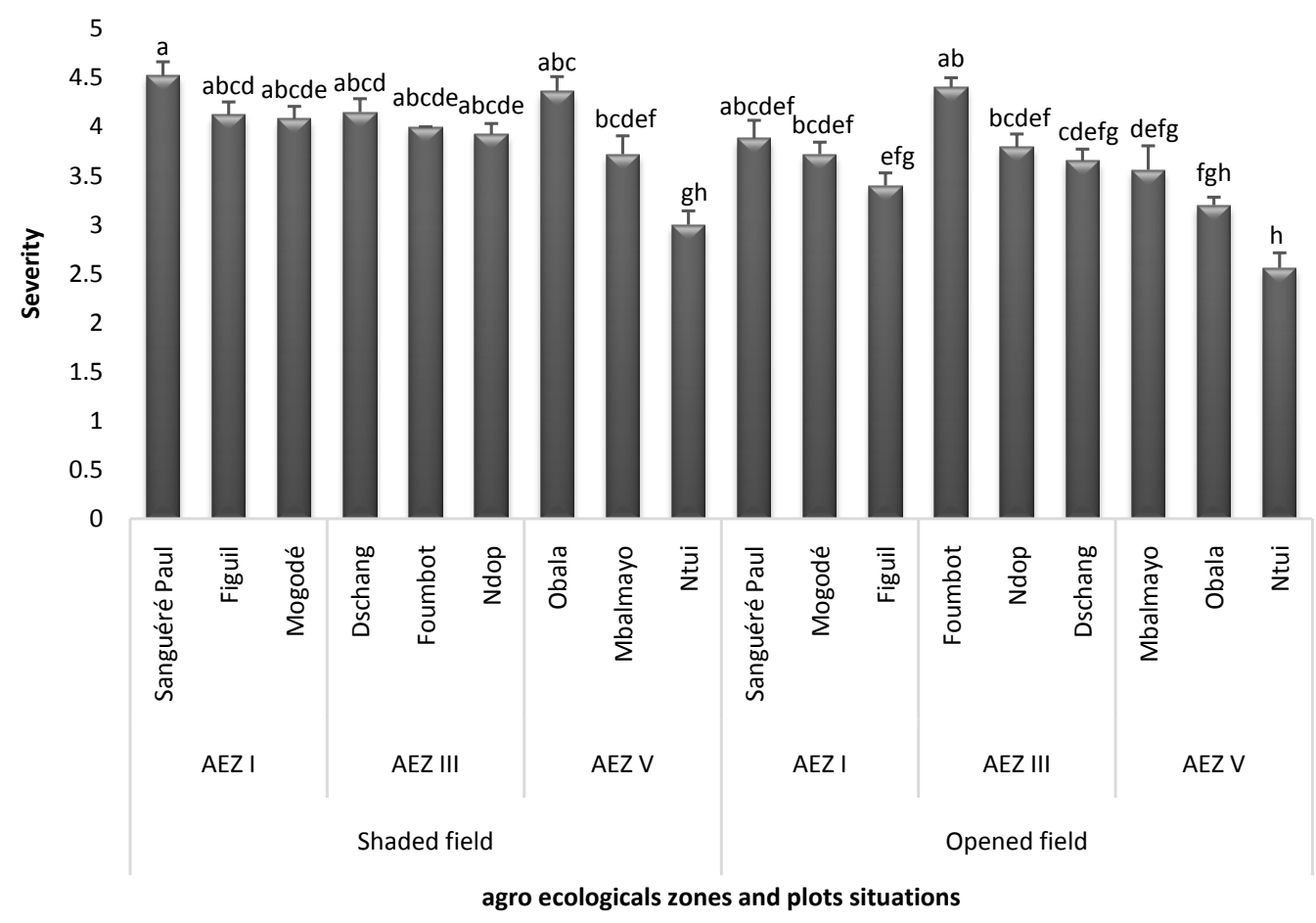

Figure 5. Severity of maize streak disease in different localities of each agro-ecological zones according to plots situations. Sample means, and error bars are standard errors of the mean. Mean followed by the same letter are not significantly different (Tukey's HSD test, $\mathrm{P}=0.05)$. AEZ: Agro-Ecological Zones.

during the dry and rainy season survey in 2018. It can be seen that, out of the 12 varieties identified during the year, Varieties CMS8704, CMS9501 and ATP had the highest incidence $(60 \%, 50 \%$ and $55 \%$ respectively) whereas CMS8501, Pop Corn, PVASYN13 had the lowest incidence (20\%, 19\% and 21\% respectively). The highest MSD severity was recorded on varieties PVASYN6, ACRO and CMS9501 (score 4; 4 and 3.5 respectively).

Figure 7 shows the effect of maize varieties on MSD incidence and severity of during the dry and rainy season survey in 2019. It can be seen that, out of the 17 varieties identified during the year, Varieties CMS8704, Doux local, Shaba and ATP had the highest incidence (65\%, 58\%, 45\% and 45\% respectively) whereas Kassai, ACRO6, MADJSYN13 had the lowest incidence $(15 \%, 16 \%$ and $18 \%$ respectively). The highest MSD severity was recorded on varieties Shaba, TZComp4 and ATP (score 4; 4 and 4 respectively).

\subsection{Serological Analysis of Leaves Sample}

Table 2 shows the reaction of maize leaf samples to antibodies Maize streak virus. It can be seen from this table that, all Cameroonian maize leaf samples tested positive for MSV in the polyclonal antibody ELISA test.

\subsection{Molecular Analysis of Maize Leaves Sample}

Table 3 shows that the MSV-CAM isolates were 99\% identical to the dominant 


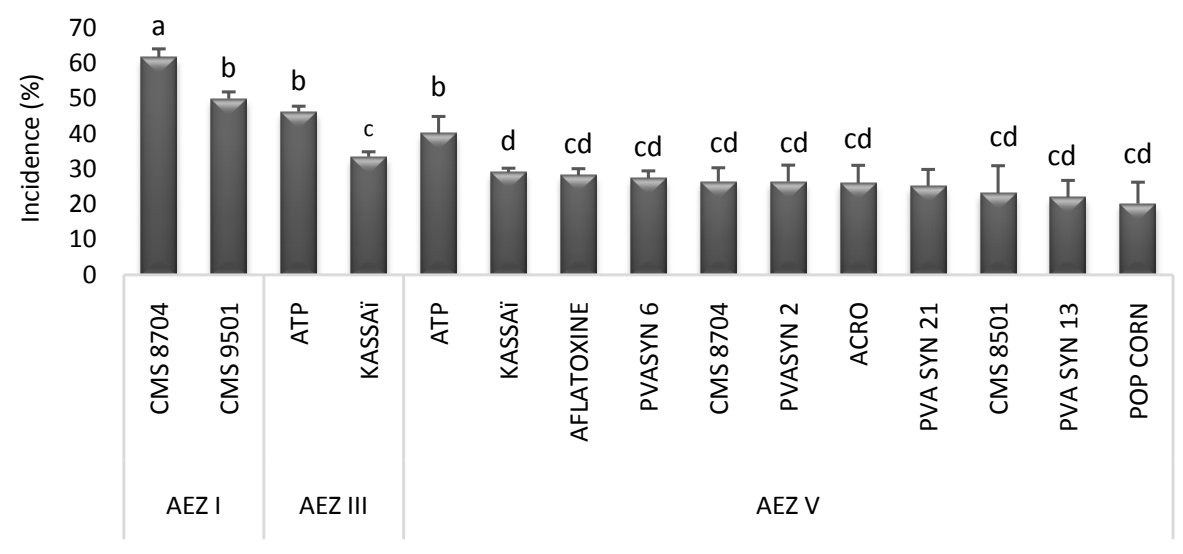

Maize varieties and agro ecologicals zones

(a)

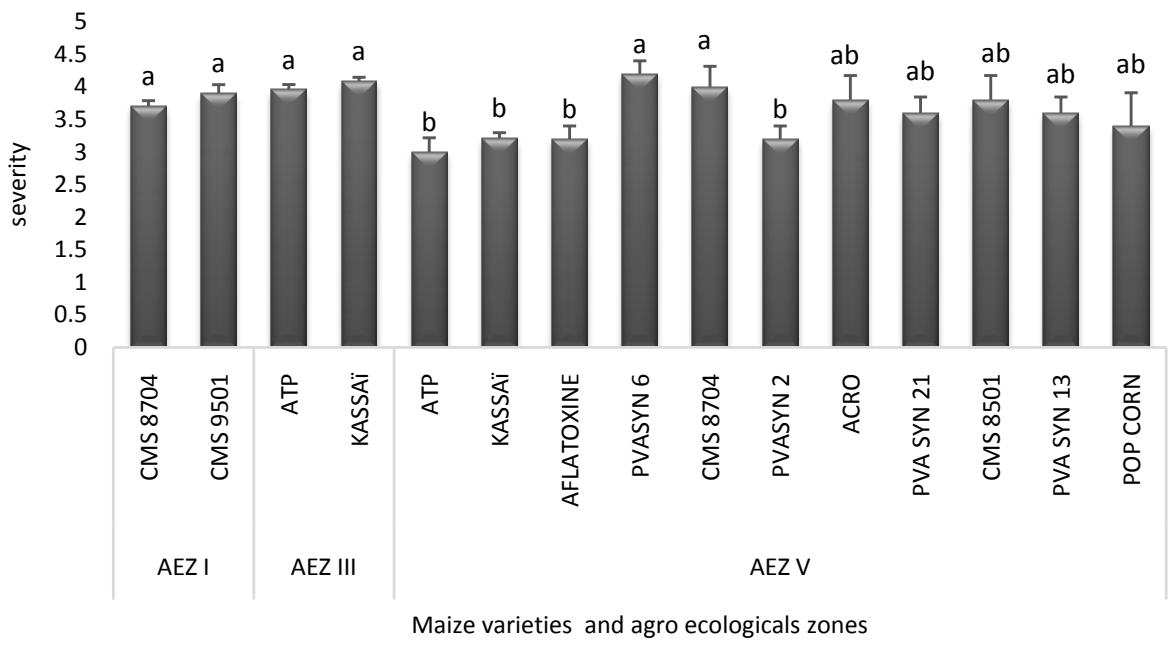

(b)

Figure 6. Incidence (a) and severity (b) of maize streak disease during the year 2018 according to maize varieties. Sample means, and error bars are standard errors of the mean. Mean followed by the same letter are not significantly different (Tukey's HSD test, $\mathrm{P}=$ 0.05). AEZ: Agro-Ecological Zones.

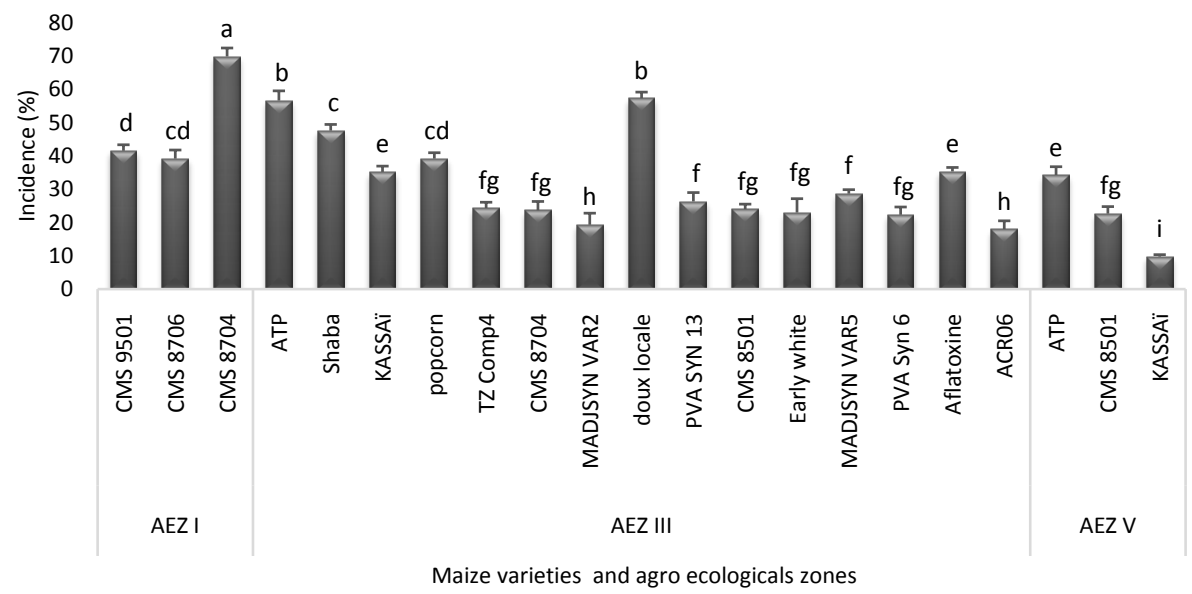

(a) 


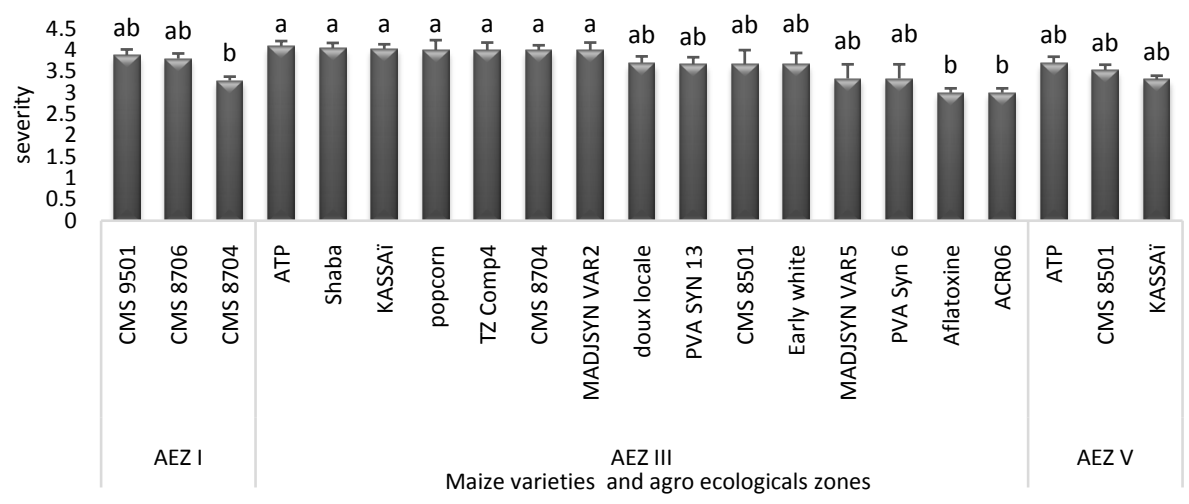

(b)

Figure 7. Incidence (a) and severity (b) of maize streak disease during the year 2019 according to maize varieties. Sample means, and error bars are standard errors of the mean. Mean followed by the same letter are not significantly different (Tukey's HSD test, $\mathrm{P}=$ 0.05). AEZ: Agro-Ecological Zones.

Table 2. Reaction of maize leaf samples to antibodies Maize streak virus.

\begin{tabular}{|c|c|}
\hline Samples & $\mathrm{A}_{405 \mathrm{~nm}}$ \\
\hline West Noun ATP & 1.04 \\
\hline M 1216-2 maroua & 1.11 \\
\hline TZL COMP 1-WC6 maroua & 1.2 \\
\hline EVDT maroua & 2.85 \\
\hline Nord-Ouest Ngoketunjia ATP & 1.91 \\
\hline M 0926-8 Garoua & 1.45 \\
\hline M 1226-2 Mbalmayo & 1.13 \\
\hline TZL COMP1/ZDP-SYN 1 Maroua & 2.01 \\
\hline CMS 9015 Garoua & 2.32 \\
\hline Obatampa soukoundou & 2.53 \\
\hline Obatampa soukoundou & 1.87 \\
\hline Dongamantung ATP & 2.55 \\
\hline Ouest Menoua Kassaï & 1.1 \\
\hline MSV Positive control & 3.39 \\
\hline Healthy maize & 0.19 \\
\hline Buffer control & 0.18 \\
\hline
\end{tabular}

reference isolates in the association of each variant sequence or recombinant strain in the samples tested.

Table 4 shows that there is a positive correlation between Cameroonian MSV isolates and IITA reference isolates. However, there is no correlation between Kassaï from Menoua and ATP from Dongamantung isolates, nor correlation 
Table 3. Details on the MSV genes used for analysis.

\begin{tabular}{cc}
\hline Genes & Countries \\
\hline MSV-IITA (reference) & Nigeria \\
MSV-CAM West Menoua ATP & Cameroon \\
MSV-CAM West Noun ATP & Cameroon \\
MSV-CAM West Menoua Kassaï & Cameroon \\
MSV-CAM North-West Dongamantung ATP & Cameroon \\
MSV-CAM North-West Ngoketunjia ATP & Cameroon \\
MSV-CAM Obatampa Soukoundou & Cameroon \\
\hline
\end{tabular}

Table 4. Estimation of the evolution of divergences between genomics sequences of MSV analyzed base on the model of composite Maximum Likelihood using MEGA6.

\begin{tabular}{|c|c|c|c|c|c|c|}
\hline & 1 & 2 & 3 & 4 & 5 & 6 \\
\hline MSV-CAM West Menoua ATP (1) & 0.01 & & & & & \\
\hline MSV-CAM West Noun ATP (2) & 0.01 & 0.01 & & & & \\
\hline MSV-CAM West Menoua Kassaï (3) & 0.01 & 0.00 & 0.01 & & & \\
\hline MSV-CAM North-West Ngoketunjia ATP (4) & 0.01 & 0.01 & 0.01 & 0.01 & & \\
\hline MSV-CAM Obatampa Soukoundou (5) & 0.00 & 0.00 & 0.00 & 0.00 & 0.01 & \\
\hline MSV-CAM North-West Dungamatung ATP (6) & 0.01 & 0.01 & 0.01 & 0.01 & 0.01 & 0.01 \\
\hline
\end{tabular}

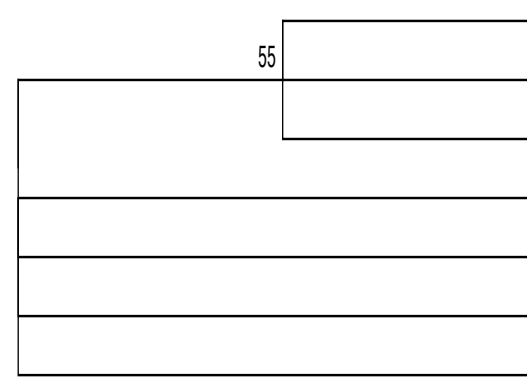

MSV-CAM West Menoua ATP

MSV-CAM North-West Dongamantung

MSV-CAM Menoua kassaï

MSV-IITA (reference)

MSV-CAM West Noun ATP

MSV-CAM Obatampa Soukoundou

MSV-CAM North-West Ngoketunjia ATP

Figure 8. Phylogenetic tree of Cameroonian isolates of MSV from model of Composite Maximum Likelihood using MEGA6.

between Obatampa from Soukoundou and ATP from Dongamatung and Ngoketunjia isolates.

Figure 8 shows the Cameroon isolates and the IITA reference isolates in two groups. The isolates MSV-CAM Northwest Ngoketunjia ATP, MSV-CAM Northwest Dongamantung ATP and MSV-CAM Menoua kassaï belong to the same group. The isolates MSV-CAM West Noun ATP, MSV-CAM West Noun ATP and MSV-CAM North-west Ngoketunjia ATP are similar to the reference isolate (MSV-IITA) and belong to the same group.

\section{Discussion}

The incidence and severity of maize streak disease varied across the different 
agro-ecological zones of Cameroon and were higher in the dry season and in shaded field. Temperatures are generally higher in the dry season than in the raining season, which would have favoured the development of the disease in the dry season. These results are similar to those of Matthew et al. [22] who reported that several viral diseases are more virulent when temperatures are high. In addition, in the dry season the cultivated areas are reduced and are located in lowlands where grasses belonging to the poaceae family are reservoirs for the vectors of MSV. During dry season, populations of grasses and maize decrease, causing the reduction in vectors food; as a result, the vectors migrate to the only grasses they can find in order to survive and transmit the disease to the only maize and grass population. The higher incidence and severity of shade-borne MSV is believed to be due to the relatively high temperatures and humidity. This is because in the open fields the heat is dry, whereas in shaded fields there is always moisture that allows the development of the Cicadulina spp. Temperature is one of the determining environmental parameters in vector-borne viral diseases. It affects the vector and the process of disease transmission. Temperature and humidity have led to geographical restriction and variation in the incidence and severity of MSD [23].

The incidence of disease in corn fields is proportional to the abundance of reservoirs; it is not until 3 to 4 weeks after the start of the rainy season that the number of reservoirs becomes significant [10]. In Cameroon, especially in agro-ecological zones I and III characterized by a very abundant grass flora of the poaceae family, the incidence of MSV is higher. The natural hosts of MSV play an important role in the epidemiology of maize streak. In maize-growing areas, maize fields favor a temporary increase in the host range of MSD [24] [25]. Maize plants first infected from reservoirs then greatly increase the source of inoculum. Leafhoppers migrating from fields to wild Poaceae will inoculate the virus to new hosts [26]. This explains the particularly high incidence in the localities of Mogodé, Figuil and Ndop. Quantitative variation in the grass flora at different times of the year could provide an explanation for the observed spatial distribution of MSV. This distribution is closely dependent on rainfall. According to the agro-ecological zones, the first weeks of the rainy season are in March for zone III and May for zone I where the grass flora is established on the non-irrigated plots allowing vectors to migrate from old plants in the market gardens to young plants in these non-irrigated plots. Since most farmers wait 2 to 3 weeks after the rains before planting, Cicadulina spp. have time to establish themselves in the grassy herbaceous plants and then migrate to the maize fields after emergence. Between May, August and September, the herbaceous flora is at its peak. In October most grasses reach the end of their cycle and only perennial and long-cycle species are found.

Maize varieties had different responses to Maize Streak Virus. Bua et al. [27] Shepherd \& Martin [28] reported that: the genetic potential of each maize variety confers disease resistance or not. According to Bosque-Perez [29] varieties 
have a great influence on the expression of viral diseases. Viruses multiply rapidly in susceptible varieties and slowly in tolerant varieties. Obatampa maize varieties are known to be resistant to Maize streak virus in the transition zone in Ghana [30] [31]. In this study, this variety does not seem to be as resistant in the Sudano-Sahelian agro-ecological zone of Cameroon where it is grown.

\section{Conclusion}

Among the five agro-ecological zones of Cameroon, Zones I and III had the highest incidence and severity of MSV due to their agro-ecological conditions which favored growing of considerable population of MSV host plants. It is in these maize-growing zones of Cameroon that the risk of streak epidemics is greatest. Shaded fields are the most attacked, hence it is necessary to avoid planting maize under trees or in the shade, as these later provide suitable conditions for development of Maize streak virus. It is important to develop a control strategy to limit yield losses due to maize streak disease. However, early planting, while the source of primary inoculum is relatively low, could reduce the most dreaded early infections and thus minimize the effect of streak disease on maize yields.

\section{Acknowledgements}

The authors wish to thank IRAD (Institue de la Recherche Agricole pour le Developpement), IITA (International Institute of Tropical Agriculture) and University of Dschang for collaboration on this work. Gratitude goes especially to the farmers in all the AEZ for accepting working in their farm and for the important information provided for this work.

\section{Conflicts of Interest}

The authors declare no conflicts of interest regarding the publication of this paper.

\section{References}

[1] Tandzi, N.L. and Mutengwa, S.C. (2020) Estimation of Maize (Zea mays L.) Yield Per Harvest Area: Appropriate Methods. Agronomy, 18, 10-29. https://doi.org/10.3390/agronomy10010029

[2] Onu, E., Natalia, P., Gideon, K., Vincenzo, F. and Anita, R.L. (2018) Sub-Saharan African Maize-Based Foods: Technological Perspectives to Increase the Food and Nutrition Security Impacts of Maize Breeding Programmes. Global Food Security, 17, 48-56. https://doi.org/10.1016/j.gfs.2018.03.007

[3] Goudoungou, J.W., Ndjonka, D., Haman, K.T., Suh, C. and Nukenine, E.N. (2017) Influence of Maize Grain Moisture Content on the Insecticidal Efficacy of Wood Ash, Leaf Powder and Diatomaceous Earth against Maize Weevil, Sitophilus zeamais Motschulsky (Coleoptera: Curculionidae). Journal of Entomology, 14, 13-23.

[4] Folefack, A. (2017) Comparing the Benefits between Producing Maize for Seeds or Consumption in Cameroon. Tropicultura, 35, 87-101. 
[5] MINADER (2019) Rapport de présentation de la filière maïs au Cameroun le 28 février 2019. 2.

https://www.investiraucameroun.com/index.php/agriculture/0103-12236

[6] INS (2018) Evaluation des importations des produits alimentaires de grande consommation et impacte sur l'économie nationale en 2017. $11 \mathrm{p}$. http://www.statistics-cameron.org

[7] Brian, E., Isabirye and Ivan, R. (2016) Current and Future Potential Distribution of Maize Chlorotic Mottle Virus and Risk of Maize Lethal Necrosis Disease in Africa. Journal of Crop Protection, 5, 215-228. https://doi.org/10.18869/modares.jcp.5.2.215

[8] Alegbejo, M.D., Olojede, S.O., Kashina, B.D. and Abo, M.E. (2002) Maize Streak Mastrevirus in Africa: Distribution, Transmission, Epidemiology, Economic Significance and Management Strategies. Journal of Sustainable Agriculture, 4, 35-45. https://doi.org/10.1300/J064v19n04 05

[9] Sunday, O., Matthew, D., Alegbejo, A.O. and Olufemi, O. (2011) Relatedness of Maize Streak Virus in Maize (Zea mays L.) to Some Grass Isolates Collected from Different Regions in Nigeria. African Journal of Agricultural Research, 6, 5878-5883. https://doi.org/10.5897/AJAR11.1351

[10] Asare-Bediako, E., Taah, K.J.J., Van der Puije, G., Amenorpe, G. and Appiah-Kubi, A. (2019) Evaluation of Maize (Zea mays L.) Genotypes for High Grain Yield and Resistance to Maize Streak Virus Infections under Diverse Agro-Ecological Zones. Research Journal of Plant Pathology, 2, 11.

[11] Kamal, S. and Raj, S.M. (2013) Molecular Approaches towards Analyzing the Viruses Infecting Maize (Zea mays L.). Global Journal of Virology and Immunology, 1, 90-106.

[12] Leke, W.N., Njualem, D.K., Nchinda, V.P., Ngoko, Z., Zok, S., Ngeve, J.M., Brown, J.K. and Kvarnheden, A. (2009) Molecular Identification of Maize Streak Virus Reveals the First Evidence for a Subtype A1 Isolate Infecting Maize in Cameroon. Plant Pathology, 58, 782. https://doi.org/10.1111/j.1365-3059.2009.02133.x

[13] IRAD (2016) Description des zones agro-ecologique du Cameroun. 3 p.

[14] Bello, O.B., Ganiyu, O.T., Wahab, M.K., Azeez, M.A., Abdulmaliq, S.Y., Ige, S.A., Mahmood, J., Oluleye, F. and Afolabi, M.S. (2012) Yield and Disease Reactions of Quality Protein Maize Varieties in the Southern Guinea Savanna Agro-Ecology of Nigeria. Journal of Agriculture and Forestry, 2, 203-209.

[15] Donson, J., Lagat, M., Kimani, M. and Kuria, A. (2008) Quantitative Trait Loci (QTLs) for Resistance to Gray Leaf Spot and Common Rust Diseases of Maize. African Journal of Biotechnology, 7, 3247-3254.

[16] Clark, M.F. and Adams, A.N. (1977) Characteristics of the Microplate Method of Enzyme Linked Immunosorbent Assay for the Detection of Plant Viruses. Journal of Genomic and Virology, 34, 475-483. https://doi.org/10.1099/0022-1317-34-3-475

[17] Thottappilly, G., Bosque-Pérez, N.A. and Rossel, H.W. (1993) Viruses and Virus Diseases of Maize in Tropical Africa. Plant Pathology, 42, 494-509.

https://doi.org/10.1111/j.1365-3059.1993.tb01529.x

[18] Tamura, K. and Nei, M. (1993) Estimation of the Number of Nucléotide Substitution in the Control Region of Mitochondrial DNA in Humans and Chimpanzees. Molecular Biology and Evolution, 10, 512-526.

[19] Van Antwerpen, T. and Rutheford, R.S. (2008) Increased Risk of New Virus Infection in the South African Sugarcane Industry: Preparing for the Future. Proceeding 
South African Sugar Technologist's' Association, 81, 365-380.

[20] Wichura, M.J. (2006) The Coordinate Free Approach to Linear Models. Cambridge Series in Statistical and Probabilistic Mathematics. Cambridge University Press, Vol. 14, 978-521. https://doi.org/10.1017/CBO9780511546822

[21] Kumar, S. and Nei Tamura, M. (2004) MEGA3: Integrated Software for Molecular Evolutionary Genetics Analysis and Sequence Alignment. Briefings in Bioinformatics, 5, 150-163. https://doi.org/10.1093/bib/5.2.150

[22] Matthew, D., Alegbejo, O. and Olalekan, B. (2005) Relationship between Some Weather Factors, Maize Streak Virus Genus Mastrevirus Incidence and Vector Populations in Northern Nigeria. Journal of Plant Protection Research, 45, 190-212.

[23] Magenya, O.E., Mueke, J. and Omwega, C. (2008) Significance and Transmission of Maize Streak Virus Disease in Africa and Options for Management. African Journal of Biotechnology, 7, 4897-4910.

[24] Damsteegt, V.D. (1983) Maize Streak Virus: I. Host Range and Vulnerability of Maize Germ Plasm. Plant Disease, 67, 734-737. https://doi.org/10.1094/PD-67-734

[25] Staceyl, H., David, B., Amanda, C. and Nora (2014) Plant-Mediated Effects of Host Plant Density on a Specialist Herbivore of Solanum carolinens. Ecological Entomology, 39, 217-225. https://doi.org/10.1111/een.12088

[26] Traoré, N., Seydou, Dabiré, A.R., Dakouo, D., Zida, K. and Ouedraoo, I. (2004) Inflence de la succession des generations de Cicadulina mbila Naudé dans les conditions artificielles d'elevage sur l'efficacité de transmission du virus de la striure du maïs au Burkina-Fasso. African Crop Science Journal, 12, 343-349.

https://doi.org/10.4314/acsj.v12i4.27896

[27] Bua, B. and Chelimo, B.M. (2010) The Reaction of Maize Genotypes to Maize Streak Virus Disease in Central Uganda. Second FORUM Biennial Meeting, Entebbe, 20-24 September 2010, 293-297.

[28] Shepherd, D.N., Martin, D.P., Van Der Walt, E., Dent, K., Varsani, A. and Rybicki, E.P. (2010) Maize Streak Virus: An Old and Complex "Emerging” Pathogen. Molecular Plant Pathology, 11, 1-12. https://doi.org/10.1111/j.1364-3703.2009.00568.x

[29] Bosque-Perez, N.A. (2000) Eight Decades of Maize Streak Virus Research. Virus Research, 71, 107-121. https://doi.org/10.1016/S0168-1702(00)00192-1

[30] Blankson, D., Asare-Bediako, E., Frimpong, K.A., Ampofo, E., Taah, K.J. and Van der Puije, G. (2018) Incidence and Severity of Maize Streak Disease: The Influence of Tillage, Fertilizer Application and Maize Variety. African Journal of Agricultural Research, 13, 551-560. https://doi.org/10.5897/AJAR2017.12873

[31] Asare-Bediako, E., Kvarnheden, A., Van der Puije, G.C., Taah, K.J. and Agyei, F.K. (2017) Spatio-Temporal Variations in the Incidence and Severity of Maize Streak Disease in the Volta Region of Ghana. Journal of Plant Pathology and Microbiology, 401, 2157-7471. https://doi.org/10.4172/2157-7471.1000401 